\title{
Mitológicas: a invenção do Brasil
}

FRANK LESTRINGANT

Traduçăo e apresentaçăo de LUIZ DANTAS e ALCIR PÉCORA

LUIZ DANTAS $E$ ALCIR PÉCORA sâo ptolessores de Teoria Literária da UNICAMP.

- Excepcionalmente as notas deste lexto se encontram no final do artigo. devido a problemas de ordem técrica

\section{NOVAS IMAGENS DO MUNDO Novo}

Impresstona vivamente a quantidade e qualtdade dos trabalbos de Frank Lestringant, fovem professor de Lteratura francesa do Renasctmento na Universidade de Lille-III. Nascido em 1951, é autor de vários ensatos em colaboraçao, além de quatro livros solos (Agrippa d'Aubigné: Les Tragiques, Paris, Presses Universitatres de France, 1986; Le Huguenot et le sauvage. L'Amérique et la Controverse Coloniale, en France, au Temps des guerres de Religion, Parts, Aux Amateurs de livres, 1990; L'Atelier du Cosmographe ou I'Image du Monde à la Reinassance, Paris, Albin Michel, 1991; e André Thevet, Cosmographe des Derniers Valois, Genebra, Droz, recém-lançado em agosto deste ano). Os três túltimos, em particular, formam uma acurada trilogia em torno da literatura ensejada pelas expediçóes francesas à América, a partir da segunda metade dos quinbentos, com especial destaque para a que tematiza a França Antártica, intentada vamente em terras cartocas. E Lestringant ainda editou três textos de André Thevet Singularités de la France Antarctique, Paris, La Découterte/Maspéro, 1983; Voyages en Égipte des années 1549. 1552: Jean Chesneau - André Thevet, Cairo, Institut Français dÁrcbebologie Ortentale, 1984; e Cosmographie du Levant, ediçdo critica, Genebra, Droz, 1985) e outro de Clément Marot.

Trabalbando privilegiadamente com inst rumentos da filologia, da estiIfstica e da retórtca, a par de evidente interesse et nográfico e erudiçao bumantsta, os estudos de Lestringant têm introduzido algumas bipóteses e linbas de pesquisa bastante consistentes e originais. Uma delas, que valeria a pena destacar aqui, refere-se ao estabelecimento de uma relação essenctal entre a construçao da figura do "bom selvagem" e a revoluçäo metodológica operada nos relatos bistóricos dos viajantes quinhentistas. Grosso modo, esta relaçāo poderia ser esquematizada em torno de três eixos de oposiçäo. O primeiro, o da "corografia" (a descrição particularista de tradiçāo medieval) versus " cosmografia" (o modelo ditado pelas grandes navegaçöes do Renascimento, com seu traçado abstrato, apropriado ao desígnito expansionista); o segundo, o da " autópsia" (alegaçao de testemunbo direto do fato) versus " confirma. çăo" (sistema de coincidencta de dados entre vártos relatos); o tercetro, enfim, que confronta os dois termos da oposiçáo anterior a " abstratiza. çăo" (generalizaçâofilosófico-pedagógica das particularidades etnograficas).

Ainda no interior desta perspectiva, as decorrênctas importantes de natureza epistemológica que discute, Lestringant associa outras, sob o stgno novamente atual da ética, relatitias sobretudo aos métodos do 
" revisionismo bistóricor e a questão moral da verdade na bistória.

Outra via dos estudos de Lestringant trata das mudanças da tmagem renascentista do fndto americano no interior do cbamado " corpus buguenote sobre a Américat, De Léry a Chauveton, de Du Plessis-Mornats a Laudonnière, de Le Challeux a La Popelintere, de Montatgne a Lescarbot, entre outros, Lestringant investiga as diferentes expectattuas com que a Causa protestante tomara o Selvagem americano como maneira de figurar e repropor, tanto internamente a sua comunidade, quanto exotertcamente, os perigos de sua situaça francesa e européta face ao " maquiaveltsmo da gente ttaliana (atualizado na Regente Catarina de Médict e na polftica sinuosa e voluntarista dos tiltimos Valots) e de Espanba, que tratava, no século XVI, de empalmar o mundo que recémvinba de ser descoberto com a brutalidade da Conquista, de que o corpus buguenote" providenctara os ecos borrortzados da "leyenda negra " . O trabalbo de Lestringant, neste ponto, demonstra sua argúcta no exame da importante tconografia das Grandes Descobertas, que deu farta muntça ds propagandas antagontcas de buguenotes e católicos. Artistas como Tbéodore de Bry e Jacques Le Moyne de Morgues alinbam-se entre os primetros, enquanto os segundos, em diferentes momentos, vao elaborar sua pintura de contra-ataque sob a ortentaça, entre vários, do proprio Tbevet, bomem da Liga - que se destncumbe desta tarofa, exemplarmente, na produçao de seus Retratos Verdadeiros -, do flamengo Ricbard Verstegen e do jesufta Louts Ricbeome.

Entretanto, para buscar as tmagens do Novo Mundo que resultam das lentes de Lestringant, detxemos os planos gerats e foquemos, por um instante, o captulo que vimos de traduzir, "Mitológicas: a invença do Brasif, o tercetro do citado L'Atelier du Cosmographe. Basicamente, ele se propōe como analise minuciosa do tipo de investimento cognitivo proporcionado pelo modelo cosmografico desenvolvido por Tbevet. $E$, mats prectsamente, procura avaliar o admirátel peso espectfico que recebe, nas várias obras do cosmografo de quatro rets de França, o Selvagem do Brasil - personagem que André Tbevet conbecen pessoalmente nas poucas semanas que esteve cat vindo com Villegagnon em meados de novembro de 1555, já ao final de janeiro de 1556 esta de safda para o seu pafs, apos passar adoentado boa parte deste breve perfodo.

Isto nao impediu, entretanto, como se vai ver a seguir, que o tmpacto desta " autopsia" fosse radical e acabasse por contaminar progressivamente o mapa cosmograftco universal de Tbevet. A mitologia das naçös indigenas do Brasil vaf cbegar mesmo a concorrer ao lugar retorico de andlogo princtpal de suas singularidades com a maquinaria cosmologica classica, obrigatória entre doutos renascentistas, que Thevet e os seus secretarios manipulavam com rudeza semelbante, e menos gosto. talvez, do que o vivamente experimentado diante da fabula tupinamba. Finalmente, para factlidade de letitura do captitulo a seguir, julgamos útil relacionar as obras do cosmografo real que sao abordadas af, alem da soltiaria de Jean de Léry, seu adversário de crença e profissaio.

Eis as do franciscano Tbevet:

CL. - Cosmografia do Levante (1554 e 1556)

GI - Grande Insular (c. 1588)

HI - Retratos Verdadeiros e Vidas dos Homens llustres (1584)

H2V - História de duas Viagens as f́ndias Austrais e Ocidentais (c. $1587-88$ )

SFA - As Singularidades da França Antártica (1557)

E a do buguenote Léry:

H1V - História de uma Viagem feita a Terra do Brasil (1578 e 1580)

É mats do que bora de conbecer o que Lestringant tem a dizer - que o faça em portugues, confessamos nós, os tradutores, nâo foi tarefa das
mais faceis. 


\section{O TROPISMO BRASILEIRO}

En parcourant les

espaces vierges, (les

navigateurs des

anciens siècles)

étaient moins

occupés de

découvrir un

noveau monde que

de vérifier le passé

de l'ancien. Adam,

Ulysse leur étaient

confirmés.

(Claude

Lévi-Strauss, Tristes .

Tropiques, Paris,

1955, p. 80)
Em vista das dez semanas efetivamente passadas na Guanabara por Thevet, o Brasil ocupa em sua obra um lugar desmedido. Não somente as Singularidades de 1557 sẳo na maior parte consagradas a ele, mas a França Antártica, perdida oficial. mente em 16 de março de 1560, povoa de lembranças numerosas os quatro tomos da Cosmografia Universal. Um livro todo, o livro XXI, está preenchido com a descriçăo dos índios tupinambás do Rio de Janeiro. Vai até o ponto de os Retratos Verdadeiros elegerem, entre os chefes das tribos antropofagas do litoral brasileiro, dois " homens ilustres", a saber, o temivel Cunhambebe, de que foi prisioneiro Hans Staden, o arcabuzeiro de Hesse, e Nacol-Absu, "Rei do Promontório dos Canibais" (1). Nos manuscritos deixados por Thevet ao morrer, a natureza e os povos da França Antártica crescem ainda em importância: a História de duas Viagens as Indias Aus. trais e Ocidentais representa o estágio quase definitivo de uma nova versấo ampliada da viagem ao Brasil, a mais rica do ponto de vista documental(2). Quanto ao inédito Grande Insular, ele exibe $\mathrm{cm}$ oito mapas, dos quais quatro se conservam até hoje, um conjunto topográfico sem precedente sobre as regiôes ocupadas de maneira temporária pelos franceses entre Macaé e Angra dos Reis(3).

De 1557 a 1592, o Brasil meridional constitui, em última análise, um ponto de referência constante em Thevet. Termo de comparaçâo necessário para descrever os prodigios naturais e morais dos três outros continentes, ele serve, por exemplo, para compreender a etologia singular do camaleão da África e da Ásia, a partir do náo menos maravilhoso caso do bradípode com apetite de passarinho(4). Para maior escândalo de Belleforest, e dos doutos, indignados que se pudesse conceder semethante interesse a umas poucas braças de terra selvagem, Thevet erige a sua "América" , a saber, uma parte mínima do Brasil, em paradigma do espaço longínquo.

Trata-se de descrever o hipopotamo ou cavalo-marinho, que se esconde no rio de Manicongre na África? Impóe-se o paralelo com este rio cuja embocadura se situa " próxima ao Promontório dos Canibais", e que "estes comedores de homens chamam de Toluilq, palavra etíope, que significa exatamente Dentes Grandes" . Ao encalço da palavra nômade, o animal se desloca além-Atlântico, onde se descobre, contrariamente a toda e qualquer expectativa, "destas (bellues) marinhas, pouquissimo consideradas pelos Bárbaros, pelo pouco prazer c contentamento que elas Ihes dão: e chamam-nas em sua algaravia Naxabaquy, isto é, Pouca Coisa" (5).

Quer Thevet estabelecer, a respeito do "golfo Arábico" ou mar de Oman, um catálogo de "golfos desconhecidos dos Antigos"? Os exemplos tirados do Novo Mundo precipitam-se sob sua pena para chegarem, de maneira previsível, a baía de Guanabara ou "Janere" ,

" ali onde por muito tempo me demorei, à entrada da qual fizemos nosso forte, por temor de sermos surpreendidos pelos Bárbaros da terra, ou outros quaisquer" (6).

Em virtude do modelo cosmográfico, que faz conjugarem-se os extremos, extrai, segundo os círculos do céu, equivalências laterais do Oriente no Ocidente ou oposiçôes verticais do Norte ao Sul, o Brasil torna-se o termo de comparaçăo universal, permitindo descrever a unidade multicor da natureza e das naçôes que cobrem a terra. As equivalencias longitudinais conforme o paralelo, ou diagonais de acordo com a eclíptica, sâo nomeadas pelo simbolismo climático, mas sấo traduzidas também na estrutura dos continentes. Já nas Singularidades. Thevet observava uma similitude de percurso entre o Ganges e o Amazonas. Da mesma forma que o primeiro desses rios "separa uma f́ndia da outra, em direçấo ao levante", o rio das míticas guerreiras sem homens poderá delimitar "a f́ndia americana" com relação "à do Peru" (7). De um a outro hemisfério, uma fronteira natural se reflete c duplica, fazendo do Novo Mundo a imagem em espelho do Velho.

Entre estas duas metades, o nome comum de " Índias" traduz ainda uma solidariedade de essências. Ao combinar a metáfora espacial, de que é devedor ao erro feliz de Colombo, com a sinédoque da parte pelo todo, Thevet é capaz de constituir uma regiấo particular do Brasil num paradigma generalizável aos " novos horizontes" em seu conjunto. No plano dos costumes, os tupinambás servirão de modelo a todos os "bárbaros", a sua cultura material das mais toscas e as suas crenças supers. ticiosas representarấo uma medida comoda para avaliar o grau de selvageria ou ci- 
vilidade dos povos exóticos. Pois se é evidente que esses " coitados" sâo "os macacos dos habitantes das fndias" (8), a recíproca exige que os "Índios" no sentido lato, da Pérsia às Molucas, e da Arábia ao Catay, sejam medidos pelo côvado dos brasileiros. Dos índios orientais a comparação se estende aos árabes, aos turcos, inimigos tradicionais da Cristandade, e mesmo às mais remotas naçōes da Europa, dos moscovitas aos escoceses, passando pelos escandinavos descritos por Olaus Magnus.

A hostilidade lendária dos turcos e dos árabes, que engendrará o ditado "de Turco a Mouro", poderia dispensar qualquer glosa na época de Thevet, tanto o motivo estava em vias de se tornar tópico(9). Entretanto, o cosmógrafo julga necessário recorrer ao exemplo dos brasileiros, canibais por sede de vingança, a fim de dar a este lugar-comum o seu valor superlativo:

" Eles nấo se estimam uns aos outros mais que entre si os margajás, tupiniquins e tabajaras da Antártica, os quais é impossivel reconciliar a todos, tanto săo encarniçados" (10).

É da profissăo do cosmógrafo associar deste modo povos separados pelo intervalo dos oceanos, e descobrir conformidade e emulação entre eles.

O paraíso dos turcos, que Thevet considera alhures " grandemente licencioso" , e onde os defuntos, sentados diante de mesas postas, em meio a airosas criadas, abrigam a vontade a sua concupiscência carnal, evoca a lembrança de um "paraíso de mesma especic" que "nossos margajás" imaginam "para o repouso de seus Cberd. ptcuares, isto $\ell$, as almas de seus pais e mães falecidos". Estas almas bem-aventuradas caminham

- nos belos jardins, repletos de Avaty, que é o Painço, e de bons frutos, e muito Cauim, que é a sua branda bebida" ,

e elas "brincam continuamente com seus Pajés, que săo os seus Profetas" (11).

Poder-se-ia ver aqui um desses breves esboços de mitologia comparada de que gosta Thevet, e que o fazem vislumbrar confusamente nos mitos indigenas da América do Sul variantes da história de Melusina e do Mago Merlim, ou prolongamentos insólitos da "busca do Santo Graal"(12). O mérito de um comparativismo de tal ordem e duplo: ele permite ao cosmógrafo exibir seu saber universal e ao mesmo tempo conduzir a prova de um controle global da diversidade humana, uma vez que ele reúne em sua mão e sob o seu olhar as extremidades do mundo. De mais a mais, a comparaçấo entre os turcos e os brasileiros toma um aspecto polêmico inegável. Ofensivo para o Islâ, o paralelo tem a vantagem, aos olhos de Thevet e seus leitores, de rebaixar a religiăo detestada ao nível da "leviana crença dos selvagens" austrais(13). O monotéismo islâmico acha-se confundido com o xamanismo índio.

Marcada por valor depreciativo ligeiramente menos acentuado, a aproximação vale ainda para as superstiçôes dos povos do norte da Europa. A "idolatria dos lituanos, antes de serem cristāos" traduzir-se-ia sobretudo pela adoraçăo " de um Martelo de tamanho e espessura monstruosos", que os signos do Zodíaco teriam utilizado para liberar o Sol aprisionado numa torre(14). Deste mito singular, Thevet nâo deixa de aproximar a "bela fábula" dos selvagens da Antártica, quando imaginam que trés estrelas do céu converteram-se um dia, pela vontade de Maire-Monan, em três altas montanhas de sua terra.

A " história da ignorância deste povo" pleiteia alhures a sua possível conversão ao cristianismo. Em débito com Olaus Magnus de sua informaçâo sobre as crenças do povo de Thyle, que distingue nos estalidos do gelo os gemidos das almas do Purgatório, Thevet coloca esta sadia superstição, que tem o mérito de bombardear o avanço do luteranismo nos países escandinavos, em paralelo com a outra superstiçăo observada por ele entre " os pobres Selvagens mais que bárbaros que se encontram entre os dois Trópicos" (15). Estes sabem através de seus antepassados que, pelo canto plangente de um pássaro, "do tamanho de um Pombo selvagem", exala-se a voz dolorosa das almas ou Cberipicuares "de seus pais, mães, irmãos e amigos que padecem penas desconhecidas por eles". O canto fúnebre da ave -o Tro pbony, sem dúvida, mencionado no capítulo consagrado aos gigantes da Patagônia(16) - permite reconhecer naquelas almas rudes a presciencia da verdade professada pela igreja católica e obstinadamente combatida pelos sectários dos pretensos reformadores. 
Os selvagens saberỉo em breve "que Deus para os seus pecados thes dá tal pena" (17), e logo vão compreender a razão dos sofrimentos póstumos. Ao estender a América do Sul a liçáo do arcebispo de Upsala, militante da Contra-Reforma exilado em Roma, que via com pavor os demônios e o protestantismo conquistarem a sua pátria distante(18). Thevet coloca-se na mais estrita ortodoxia, mostrando entre os povos aparentemente mais afastados da luz divina "centelhas" do sol eucaristico que em breve brilharia sobre eles. A Cristandade perdida da Europa do Norte está prestes a se reconstituir nas latitudes austrais, na outra extremidade da terra.

O império das trevas do Brasil pagăo ressurge em outra parte a proposito do milagre de Vervins(19). O público triunfo do Santo Sacramento sobre uma possessa da Picardia evoca na memória do cosmógrafo milagres análogos obtidos sobre "Agnan Hippochi" , o diabo da Antártica: o fato é que os selvagens

" eram muitas vezes livrados, ao thes ser lido o Evangelho: a tal ponto o nome de Jesus tem força sobre as potências obscuras" .

A ignorância dos brasileiros, testemunhada pelas trevas que os envolvem, mesmo que pressagiem a conversăo futura, traduz-se também no plano da civilizaçăo material. A alta ciência da cosmografia, por exemplo, e-lhes desconhecida e sua navegação reduz-se a uma cabotagem que não perde de vista as costas. $O$ modelo serve para descrever o saber rudimentar dos marinheiros do mar Cáspio, povo que "sabe observar apenas o seu roteiro de pequena escala" (20). Desprovidos de bússolas e cartas marítimas, içando nos mastros rabos de raposa para conhecer a direçâo do vento, os "cáspios" só perdem em rudeza para os habitantes daquilo que Thevet chama, nâo sem orgulho, de "minba França Antártica" (21). Rudimentares, embora por isso mesmo frugais, os bárbaros do Brasil observam regras de uma dietética rigorosa, e escandalizam-se com carnes de porco salgado ingeridas sem precaução pelos colonos franceses, seus amigos, que lhes abreviam a vida. Nisto, aproximam-se dos preceitos, impregnados, é verdade, de superstiçâo maometana, dos árabes do Levante(22).

Vê-se entâo de que forma, alternativamente, homens da natureza ou, ao contrário, distanciados dela, os "coitados" da Antártica definem o paradigma contraditório da humanidade não-cristã. Ao inverso do que já se entrevê na História do uma Viagem de Léry ou no ensaio Dos Cantbats, de Montaigne - uma espécie de alegorizaçấo do Selvagem encarregado de encarnar, por exemplo, o reino da Natureza, a Igualdade primitiva ou a Liberdade ociosa da Idade de Ouro ovidiana -, a "América" de Thevet não preenche o espaço de nenhum conceito. Ele não é mais do que a soma de traços particulares e circunstanciais, o que vale dizer que ele condensa nele próprio um catálogo de "singularidades" irredutíveis e contraditórias. Cruel e devas. so, virtuoso e hospitaleiro, homem de honra e "grảo ladrảơ", os qualificativos aplicados a ele, alternadamente ou simultaneamente, aparecem regulados por um códi. go sempre móvel e que se molda, de detalhe em detalhe, sobre a particularidade cada vez posta em relevo.

A alimentaçâo, as crenças, a arte da guerra ou a medicina definem maneiras diversas de apreender o Selvagem e de julgá-lo segundo apreciaçôes contraditórias. Ora ele se acerca do modelo positivo esboçado por Montaigne: ignorando a medi. cina e a fisica, os brasileiros praticam os preceitos melhor que "Aristoteles, Averróis ou Avicena", pois "Natureza ensinava-lhes e ensina todos os dias o que é bom e o que é nocivo" (23). Ora ele demonstra, ao contrário, uma estupidez espantosa, de tal modo que

"a primeira vez que viram abordar e flutuar os navios nas proximidades do vasto mar que os cerca (....) julgaram e acreditaram, por jamais terem visto, nem tampouco seus pais também, tais pesadas e grandes naus, que fossem ilhotas e assim flutuassem naquele mar" (24).

É por todas as circunstâncias diversas que fazem o índio do Brasil que se inte. ressa Thevet, e nảo por aquele universal singular que vai mais tarde constituir o Homem da Natureza. Com tơda evidência, o Selvagem polimorfo, o mosaico do fran. ciscano cosmógrafo, situa-se nos antípodas do Bom Selvagem dos filosofos, pálida abstração nâo preenchida por nenhum conteúdo etnografico concreto(25).

É sabido que as modernas ciências do homem văo dar origem à recusa das sin. 
gularidades, concebidas como exteriores à razão, tanto quanto a natureza. O programa da Sociedade dos Observadores do Homem, tal como foi fixado por Gérando em 1796, condena do modo mais explícito a "curiosidade" insaciável c desordenada dos antigos viajantes, excessivamente presos ao acessório e ao exótico, e incapazes de atingir a generalidade. É então que, em lugar das velhas rapsódias cheias de bricabraque dos gabinetes de curiosidade, impōe-se o modelo, quão mais intolerante e redutor por sua própria pretensão ao universalismo, de uma antropologia fundamentalmente etnocêntrica(26).

A ausência patente da Razão unificadora empresta todo o valor à empreitada de Thevet, isto, poder-se-ia dizer, até em seus defeitos mais tangíveis. A miscelânia da investigação é produzida tal qual; nenhum achado é subtraído da atenção do leitor benévolo, tampouco o comentário menos meditado e mais anódino. As mais violentas condenaçôes - estes "brutais", estes "bestiais" selvagens -, que se encontram a cada página, são quase sempre neutralizadas na linha seguinte por elogios simétricos e, parece, igualmente sinceros e desenvoltos. Thevet nåo está isento, evidentemente, dos preconceitos políticos, religiosos ou mesmo racistas de seus contemporâneos (pois o racismo, apesar do que se diz às vezes, não é um fenômeno alheio ao século dos Grandes Descobrimentos), mas, como ele não tria absolutamente no corpus de informaçōes que possui, ter-se-ia muita dificuldade em descobrir nele essas censuras ou esses silêncios que afloram, a propósito da religiâo, por exemplo, no ensaio de Montaigne ou na História de Léry.

Paradoxalmente, a fragmentação do indio $\mathrm{em}$ acidentes diversos é que pode constituí-lo como termo de comparação universal. A "América" do Brasil austral está presente em toda parte, da Lituånia à Arábia deserta, do Egito à Islândia e do mar Cáspio à Picardia. Espalhado pelos quatro continentes no pó de estilhaços de um espelho quebrado, o Selvagem brasileiro torna-se capaz de refletir, e por isso mesmo iluminar, as mais desconcertantes e esparsas realidades. Longe de reduzir a inesgotável pluralidade do universo à empobrecedora unidade, ele conjuga $\mathrm{cm}$ sua pessoa feita de contrastes o espirito de geometria inerente ao raciocínio cosmográfico e à varicdade admirável e ao mesmo tempo decepcionante das coleçōes de rariora. Ubíquo e diverso, onipresente e inapreensível, é uma das chaves da cosmografia segundo Thevet.

Neste sentido, a revolução cosmográfica operada pelo natural de Angoulême assim como se fala em revoluçāo Coperniciana, embora o cosmógrafo se atenha, bem entendido, ao esquema geocêntrico de Ptolomeu - seria a de privilegiar uma margem, o Brasil, em relaçăo a um centro tradicional, a Europa ou o seu oposto milenar, o Oriente-Próximo mediterrâneo. Uma vez que o seu sistema descritivo tem por dupla característica ordenar-se sobre a armadura geométrica do mapa e referir-se sempre, em última análise, a sacrossanta autópsia, era-lhe preciso eleger esses dois pólos situados aproximadamente nos antípodas um do outro: o Levante da peregrinação dos anos 1549-52, e o Extremo-Ocidente austral da viagem à Guanabara no inverno de 1556. Mas o Oriente de ruínas e clichês que Thevet herda de uma tradição plurissecular, e onde ele só pode inovar sob o modo um pouco maçante da denegaçẫo, é em breve suplantado pelo brilho novo de um Brasil inaudito, cuja amplidâo náo cessa de se afirmar no decorrer das obras sucessivas. Por culpa de um Levante arcaico, cuja descrição redundante, cada vez mais apartada das fontes vivas da peregrinação, e alimentada pelas compilaçoóes facilmente identificáveis, de Paul Jove a Sansovino(27), o tropismo brasileiro domina pouco a pouco a extensão do mapa-múndi thevetiano.

Disperso sobre o orbe terrestre todo, o Brasil o é também na língua de seus aborígines. Não se encontram em Thevet - pelo menos antes do Grande Insular inacabado - nem dicionários exóticos, nem "colóquios" bilíngües como em Cartier ou Léry(28), mas frases erráticas empregadas de maneira próxima à situação de origem ou vocábulos estranhos extraviados em contextos imprevisíveis. A palavra margajat, que designa um menino travesso, vaì passar para o uso corrente na época clássica, a partir de Thevet, sem dúvida, ou de algum de seus imitadores(29). Mas o cosmógrafo emprega também o apelido Gentil Morubixaba para falar de Lutero, que teria " proibido a todos os seus discipulos e adeptos, sob pena de serem expulsos de sua Igreja, de entrar em conflito com os ministros católicos" (30). Ora o termo morubixaba qualifica, na sociedade tupinambá, os anciāos sábios que, reunidos em conselho na "casa comprida", deliberam sobre a guerra a ser iniciada. Numa passagem da Cosmografia Universal, Thevet nāo hesita em compará-los àqueles "Se- 
nhores conselheiros do Senado de Veneza, tal a gravidade e modéstia que eles mostram em seus conselhos" (31). Em outro lugar, ele apresenta um morubixaba açu ou "grâo Rei", pavoneando-se, "inteiramente nu", com a maça ao ombro, diante de Villegagnon e sua comitiva, mal desembarcaram do navio(32). É cômico evidentemente imaginar Lutero como chefe canibal e nudista, presidindo do alto de sua rede as discussốes dos adeptos. Porém nảo é certo que o leitor desprevenido tivesse saboreado o sal da situaçâo, uma vez que a palavra obscura e bárbara era explicada somente mil e seiscentas páginas adiante.

Ainda mais inesperada e quase incompreensivel é a conclusão, na coletânea dos Homens Ilustres, do capítulo consagrado a Robert Gaguin, autor do Compendium de Francorum Gestis (33). Juntando ao elogio deste representante do primeiro humanismo os de Rodolfo Agricola, do " Doutor Jasão Maynus de Milāo, reformador do Direito" (34) e do "satírico" Jean Lemaire de Belges, Thevet introduz a respeito deste último uma "alusãó" onomástica aparentemente das mais incongruentes. O escritor da Lenda dos Venezianos, "prodigiosamente picante" nas "agudezas" de sua pena afiada, seria, a julgar pelo autor da prosopografia, um historiador impar em sua obra-prima, as Ilustraçōes da Gália e Singularidades de Tróia:

" E embora alguns tenham pretendido murmurar, se se considerar atentamente as palavras deste Mair, encontrar-se-ão bem poucas maravilhas ocorridas na Cristandade, até o seu tempo, que ele não tenha tocadơn (35).

A anominaçăo Lemaire-ce Mairchega às raias do absurdo para quem ignora que um Mair (ou Matre) é o nome genérico dos herois civilizadores na cosmogonia tupinambá(36). O próprio Thevet dá a este nome o sentido primeiro de " transformador", isto é, mágico, e ele consagra nada menos do que três capítulos da Cos. mografia Universal para narrar detalhadamente os avatares míticos de Maire-Monan, Maire-Pochy e Maire-Ata(37).

Quando se sabe que Jean Lemaire, ao manter a indistinçẩo original entre mito $e$ história, tenta realçar esta através daquele, não se pode deixar de admirar a justeza relativa da alusăo proposta por Thevet. Revelando, pelo intermédio do Pseudo-Bérose d'Annius de Viterbo, as origens fabulosas das duas monarquias irmãs, alemã e francesa, desde o Dilúvio e o saque de Tróia, Jean Lemaire é comparável, num sentido, aos caraíbas (karai) ou profetas brasileiros. Ao reunir $\mathrm{em}$ suas pessoas as qualidades de xamãs e semi-deuses, eles figuram aos olhos dos índios reencarnaçốes dos Maires primitivos e sobretudo do principal deles, Maire-Monan, o autor de infinitas metamorfoses sobre si mesmo ou sobre os mais diversos objetos(38). A sua " teologia", que Thevet especifica " estar guardada, não por escrito, mas na simples memória de cada um" (39), também narrava, além das "transformaçốes" mencionadas, mitos de origem, não de uma dinastia real - obviamente -, mas invençốes tais como a cultura do milho e dos tubérculos ou o uso do fogo.

A bricolagem histórico-mítica de Jean Lemaire relaciona ainda o requinte das cortes da Borgonha e da França com o "pensamento selvagem" dos tupinambás, tal como foi descrito minuciosamente por Andre Thevet, e ornamentado com incisos irônicos. Aproveitando-se de tudo, ajustando as mais dispares tradiçốes num mesmo corpo de doutrina, o poeta de Margarida d'Áustria e de Ana de Bretanha reuniu, em torno do projeto de uma concórdia política e cultural da Europa cristâ, os materiais de uma história das origens comuns. Ora, esta é a empreitada expandida pelas Singularidades de 1557, ao ornar a liçâo dos Matrs.

\section{Polidoro Vergílio e o Pensamento Selvagem}

Os tradutores de André Thevet prestaram-Ihe um grande serviço. Em dois casos, ao menos, descobriram as suas intençốes mais obliquas e discerniram as fontes menos aparentes. Assim o alemão Gregor Horst desvendara o parentesco, e até a dependência existente entre certos capítulos da Cosmografía do Levante e as Liçбées Antigas de Coelius Rhodiginus(40). Da mesma maneira, o ingless Thomas Hacket descobriu que o modo de investigaçâo empregado por Thevet para tentar explicar as sociedades indigenas do Brasil e sua cultura primitiva era próximo do raciocínio utilizado por Polidoro Vergílio, historiador da Inglaterra e cidadão emérito do reino, em seu tratado Dos Inventores das Coisas (41).

Na epistola dedicatória de The New Found World, or Antarctike, dirigida em 1568 
a Sir Henry Sidncy, o tradutor desdobra longamente a lista dos inventores das artes e das ciências sem as quais a humanidade se encontraria nua, seria bárbara e brutal, e até escrava. São passados em revista a instituição progressiva do calendário, desde os antigos egípcios até Júlio César, via Numa e Romulus, a imposição das leis civis por ísis, o ensino da agricultura por Ceres, o início da navegação incentivado por Minos, por Netuno ou seu pai Saturno, ou ainda pelo rei Erichthas, todos eles monarcas pagãos, aos quais seria conveniente preferir Noé, o patriarca da Bíblia (42).

Este resumo de Polidoro Vergílio, cujo nome, aliás, é mencionado a propósito da invenção do calendário, que recorre sistematicamente a um modo de explicação evemerista, termina por um elogio da navegação e um convite expresso à instalação de colônias além-mar. Lamentando as delícias de Cápua onde se enterram os seus contemporâneos, " almoste abborring to beare the name of travel or payne" , Thomas Hacket exorta-os a seguir o exemplo de Alexandre, leitor fervoroso de Homero e das façanhas de Aquiles, a crer em Plutarco. Ao entregar o livro deste honorável viajante "Andrewe Tbevit" (43) ao público inglês, Hacket oferece-lhe ao mesmo tempo a oportunidade de executar aquela elevada empresa.

Em umas poucas páginas, o tradutor e editor circunscreveu o desígnio literário $\mathrm{e}$ político de seu modelo, e soube adaptá-lo à realidade da Inglaterra do seu tempo. De fato, a despeito de sua discrição neste ponto, as Singularidades prendem-se a açâo colonizadora de Villegagnon e constituem uma espécie de prospecto particularmente atraente. O programa de conquista esboçado em filigrana pela obra adapta-se doravante aos intentos ingleses para o Novo Mundo. De mais a mais, ao resumir Polidoro Vergílio no limiar de uma descrição que procede da mesma filosofia das origens, Hacket distinguiu claramente a cartada ideológica das Singularidades. Da mesma forma que Gregor Horst, na verdade, ele não fez obra de filólogo ou de historiador da literatura. O que ele vislumbra, de Polidoro Vergílio a Thevet, não é a filiaçăo linear e unívoca, mas uma comunhăo de preocupaçóes, um raciocínio análogo que recorre à comparação das tradiçốes culturais entre os povos diversos para tentar extrair um modelo geral e assentar sobre ele a superioridade da Europa cristã.

O comparativismo proposto pelas Singularidades é o fruto do trabalho obscuro de Mathurin Héret, bacharel em Medicina e helenista conhecido por suas traduçōes

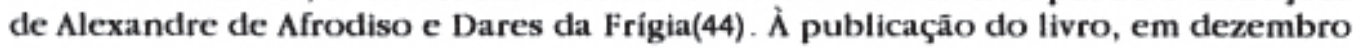
de 1557, Héret intentara um processo para reconhecimento de paternidade. Ele obteve que the fosse creditada a totalidade dos direitos, mas náo a assinatura da obra, que permanecia com Thevet. Coube sem dúvida a Héret a tarefa de rechear de referências aos autores gregos e latinos a reportagem sobre o Brasil. Vem daí a construção $\mathrm{em}$ paralelo de tantos capítulos do livro: depois de uma exposição etnográfica precisa vêm os exemplos tirados da Antigüidade, pela mediação cômoda de Plínio, por vezes alegado, ou de Polidoro Vergílio, sempre omitido. Trata-se de evocar a boa memória dos índios, que jamais esquecem o nome dos seus convidados franceses depois de os terem ouvido? Uma lista dos campeôes da arte mnemotécnica - "Ciro, rei dos persas, Cinéas, legado do rei Pirro, Mitridates, César" - é imediatamente produzida, colhida no livro II do tratado Dos Inventores das Coisas (45), para formar o fecho do capítulo. Outro exemplo: a tonsura quase monástica dos indios, justificada por uma preocupação de ordem militar (os cabelos seriam presa fácil do adversário no corpo a corpo), apela, à guisa de explicação, ao precedente de Teseu quando consagrou os seus cabelos aos deuses de Delfos, e àquele mais adequado de Alexandre, que obrigou a falange macedônia a raspá-los para que nâo se deixassem agarrar(46). A fonte, doravante, é o opúsculo de Polidoro Vergílio que dispensou Thevet ou seu secretário de recorrer às Vidas de Plutarco(47).

Da mesma maneira, o capítulo consagrado aos Pagés e Carafbas, respectivamente os curandeiros e os profetas dos tupinambás, conclui-se por uma investigaçâo da magia, que relaciona novamente o corpus brasileiro à temática recorrente das origens das artes e ciências(48). A observaçâo é ainda válida para as "visōes, sonhos e ilusôes" dos infelizes "américas", inteiramente entregues ao império de Satã: as perseguiçōes noturnas infligidas pelo "espírito mau" e os sonhos premonitórios que os visitam na manhã de um combate sẫo comparáveis às "duas espécies de adivinhação" distinguidas por Polidoro Vergílio(49). Sucessivamente, a guerra primitiva que opôe guerreiros nus e hercúleos armados de maças(50), as leis do casamento(51), o nascimento do comércio(52), a invenção da serra(53), as primeiras habitaçōes e a origem da arquitetura(54) e o modo de subsistência da antiga huma- 
nidade(55) sáo ilustrados pelo exemplo dos brasileiros

A referência a Polidoro Vergílio, onipresente na sequêencia brasileira, assegura a transição entre a bricolagem pós-humanista da Cosmografía do Levanta a novidade indizivel e sem profundidade histórica da França Antártica. Em quase todos os capitulos que formam o cerne das Singularidades obtém-se entâo uma sequência binária que associa a um motivo de ordem etnográfica uma "liçăo antiga". O movimento se repete, operando incansavelmente esta reduçáo do desconhecido ao conhecido. Da estranheza primeira, vista e relatada, retorna-se a familiaridade de um texto lido e muitas vezes comentado. $\Lambda$ conclusão substitui, entâo, ao Brasil dos Canibais a Tróia homérica, a Cítia de Herótoto ou a Idade de Ouro de Ovídio ou Virgílio. $\Lambda$ empreitada de Thevet-Héret apenas sistematiza uma tendência observável desde as primeiras relaçôes sobre o Novo Mundo.

Desde as Décadas de Pedro Mártir de Anghiera, a descoberta das "Índias novas" completa o renascimento das letras ao agir paradoxalmente no mesmo sentido. O longínquo no tempo e o longínquo no espaço definem um território comum onde a cultura clássica se encontra cm casa.

Mais exatamente, o paralelo com os costumes da Antigüidade e suas tradiçóes evemeristas confere a sociedade dos Canibais a dignidade de um objeto de ciencia. As referencias eruditas, na maior parte das vezes recebidas de segunda mão, sáo destinadas sem dúvida a colocar no mesmo pé o homem da Europa e o americano nu c antropofago. Mas, sobretudo, clas autorizam este último a penetrar no campo das "histórias". Através de um duplo processo de heroicizaçáo e de moralizaçâo, ver-se-á os " mais cruéis do universo" autorizados a competir com os homens ilustres de Plutarco: Tescu, Licurgo, Sólon e César(56). A tarefa de integração das "glorias" americanas no corpus tradicional dos grandes homens vai culminar nos Retra. tos Verdadetros Cunhambebe, Parausti, Saturiona, Paracussi rei do Prata e Nacol. Absu, pequenos príncipes da América, têm o mesmo formato das figuras de Alexan. dre, César ou Francisco I (57).

O enxerto da Antigüidade no Novo Mundo. aos cuidados de Héret, engendra uma segunda relaçáo $\mathrm{em}$ sentido inverso. Se a América é justificada pela referência aos Antigos, o Brasil, em troca, explica à Europa as suas próprias origens. É nisto que o tratado de etnografia americana representa simultaneamente um manual de arqueologia européia. Os nossos primeiros pais andavam nus, combatiam com unhadas e dentadas, a ponto de devorarem o adversário $\mathrm{em}$ caso de vitória, ignoravam a arte da forja e as regras do casamento. As suas casas cram de ramos trançados, a menos que preferissem o abrigo das cavernas. Todas estas proposiçôes encontram-se em Polidoro Vergílio. Ao passar $\mathrm{cm}$ revista os mitos civilizadores do Ocidente, o huma. nista de Urbino propőe para cada " invençáơ" (a linguagem, a religiảo. o calendário. a arte da guerra, a agricultura, a arquitetura, a navegação, o comércio e a "putaria". etc.) o nome de um ou mais heróis, semi-deuses ou profetas. Ora, esta mitologia compósita vai ao encontro dos mitos funcladores da religiảo tupinambá relatados por Thevet. O parentesco é evidente: aqui e lá, a história da humanidade reduz-se à dos grandes iniciadores. Desde então. uma baldeaşåo de um continente a outro torna-se possivel: Noé ou Dédalo tomam o lugar de Maire-Monan e Maire-Pochy. figuras usurpadoras $\mathrm{e}$ necessariamente ficticias.

Esta leitura brutalmente redutora prolonga, de fato, aquela que, definida antecipadamente por Polidoro Vergilio, denunciava as mentiras e as imposturas do paganismo antigo para exaltar, por tabela, o privilégio solitário reservado à revelaçấo cristã. Para Plínio, por exemplo, o catálogo dos inventores, no livro VII da Histórta Natural, tinha por funçáo efetuar uma distribuição geográfica dos méritos segundo os diferentes povos da bacia mediterrânea que todos, por algum motivo, honravam-se contribuindo para a felicidade comum. Aos fenícios cabia a honra da navegaçáo pelos astros, aos egípcios, a invenção do alfabeto e da tecelagem e aos frígios. a da carroça de quatro rodas. O cretense Dédalo descobrira a arte da "carpintaria". o fenício Cadmo, a extraçăo e a fundição do ouro, o tebano Tiresias, a adivinhaçấo pelo vôo e a voz dos pássaros(58).

Com Polidoro Vergílio, ao contrário, tributário aqui do Contra Áto de Flávio Josefo, uma das fontes principais de sua compilaçấo(59), a verdade última da Biblia e do povo eleito remete para o nada da fábula as pretensóes concorrentes das outras naçôes. Caim inventa a lavoura muito antes do nascimento de Ceres, deusa rebaixada à condiçâo de simples mortal. Noé suplanta Baco, Moisés não espera Hércules para inovar na arte da guerra. A voz dos Patriarcas e dos Juizes abafa, daí em diante. 
o concerto, em última análise harmonioso, das diferentes reivindicaçôes nacionais. Longe de efetuar uma síntese entre cristianismo e paganismo, o tratado Dos Inventores subordina a diversidade complementar das tradiçōes pagâs à unidade de uma verdade totalitária. Polidoro Vergílio não reconheceria no cristianismo a mais bela das " invençôes" , cuja iniciativa, afinal, como a da Criação, não coube senăo a Deus?

Sabe-se que Polidoro, aos três primeiros livros publicados desde 1499, acrescentou, vinte $\mathrm{e}$ dois anos mais tarde, cinco totalmente consagrados às origens $\mathrm{e}$ às instituiçốes da Igreja. Como observou Denys Hay(60), isto nẫo significava modificar na essência o projeto inicial. Logo de saída, o humanista de Urbino continuava, pela via aberta por Josefo em prol da cultura judaica, retomada desta vez em benefício do povo cristão, uma empreitada apologética fundada sobre a comparação mitografica.

Em sua imitaçăo, Thevet mostra-se fiel ao espírito do tratado Dos Inventores. Sente necessidade de lembrar as idades da humanidade primitiva? Ele refuta em nome do Gênese a fábula dos poctas Virgílio. " na primcira de suas Geórgicas", e Ovidio, que supuseram "viver os homens universalmente em toda a terra junto das brutas feras" (61), O Éden nāo é a Idade de Ouro, o trabalho do Adāo jardineiro afasta a humanidade, desde o início, da preguiça a que se entrega o animal(62). Ao evocar depois a "lavoura de Abel", por confusão com seu irmão Caim, e com a finalidade sem dúvida de glorificar a nobre ocupação da agricultura(63). Thevet acaba arruinando as ficçóes do paganismo cm proveito do labor original: os selvagens do Brasil. que cultivam mandioca $\mathrm{e}$ milho, ligam-se, a despeito de sua ignorância e rudeza, à humanidade trabalhadora e prometida à salvaçâo. A lição de Polidoro Vergílio milita em favor do monogenismo, estabelecendo ao mesmo tempo uma hierarquia dos saberes e das culturas.

A frente comum conjunturalmente formada entre as sagraclas Escrituras c a realidade índia quebra-se tâo logo se trate das crenças religiosas. O privilégio solitário que detém a tradição judaico-cristã face à mitologia pagã reaparece diante das " fábulas" dos amerindios tocantes às suas origens. As Singularidades comprazem-se em sublinhar entāo o contraste: a "brutalidade cega" dos pobres "américas" manifesta-se, por exemplo, na confiança que depositam em seus xamãs e vãs "feitiça-

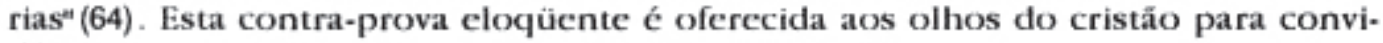
dá-lo a seguir o caminho espinhoso e ingreme da Graça. Da mesma maneira, no capitulo das visōes e perseguiçōes do espírito mau, o autor, para concluir, chama o leitor a se voltar para a Biblta e confundir na mesma reprovaçăo a idolatria dos "antigos gentios" e o respeito que os selvagens consagram a seus " Pajés ou Caratbas, vale dizer, seus semi-deuses" (65).

Não há muito a considerar da mitologia americana das origens, salvo aquilo que se concilia com a Revelaçâo, a saber, a crença num dilúvio universal de água e fogo, afirmada amplamente em toda a área brasileira e amazónica(66). No tocante aos mitos dos inventores, deixar-se-âo aos índios, quando muito, aqueles que se relacionam com produtos exóticos. Dessa maneira, melhor é apelar para a sua " traditiva" a fim de que se conheça a invençāo da cultura da mandioca, pobre Ersatz do pâo que thes falta, e esta é a parte essencial que cabe a Maire-Monan, o herói civilizador dos tupis(67). Quanto ao mais, será necessário recorrer ao ensinamento das Escrituras.

A arqueologia da Europa pela mediação da América é entäo destinada a valorizar menos um progresso contínuo de uma a outra, do que uma ruptura fundamental entre duas idades em tudo separadas: antes e depois da Revelação. Os tupis não tiveram acesso, até o presente, à era da Graça. Sua separação da verdade exprime-se de maneira muito concreta pela miséria e barbárie manifestas. A nudez e o canibalismo săo os sinais tangiveis, mas também o desconhecimento de técnicas elementares tais como a lavoura com arado, a fundiçăo do ferro e a forja dos metais, a arte eqüestre $e$ as armas de fogo.

Em suma, o Selvagem servirá para realçar o cristảo da Europa, rico no que concerne a ele mesmo, e, por menos que respeite os mandamentos, no que concerne à sua eleição divina e certeza de uma redençāo futura. Contra-exemplo radical entregue a meditação do homem que vive submisso a Deus, como mais tarde quererá Jean de Léry(68), o índio, útil pela própria distância que ele representa, pouco a pouco aparecerá como a figura condensada da criatura que vive submissa à carne, tomando entâo um valor emblemático no scio do discurso moral e teológico que o envolve. Contrariado pela visão heróica da história herdada de Plutarco e cedendo, por outro lado, ao fascínio da pulverizaçâo do diverso, este discurso, em Thevet, năo 
atinge a coerência e permanece $\mathrm{em}$ estado de esbọ̧o plausível e năo exclusivo.

A bricolagem efetuada por Héret permanece visivel: cla transparece no esquematismo de duas estruturas sumariamente embutidas que correm paralelamente de capítulo $\mathrm{cm}$ capítulo. Sem dúvida, Polidoro Vergílio tem a última palavra, sempre mobilizada no instante final, para rematar uma questão. O seu aparelho genealogico suplanta a tosca mitologia dos tupinambás, mas a integra parcialmente. Cada vez menos controladas a medida que se amplifica a obra brasileira de Thevet, passando pelas etapas ulteriores da Cosmografia Universale da Histórla de Duas Viagens, as belas "fábulas" dos tupinambás nảo tardarâo muito a quebrar a construção precária reunida pelo escriba de 1557 . A partir de 1575 , com a série polifónica dos mitos que narram a criaçấo do mundo, as metamorfoses e a morte de Maire-Monan, o heroi cultural, o dilúvio universal $\mathrm{e}$ as diferentes idades da humanidade, Thevet compó verdadeiras Mitológicas. Nâo contente, por exemplo, de referir a narrativa do dilú. vio e dos dois irmâos, a cla justapóe duas variantes distintas(69).

Sem dúvida, é preciso ver aí a preocupaçáo em aproveitar a menor sobra, e neste sentido o cosmógrafo mostra que assimilou o método da perfeita bricolagem, mas $e$ possivel também supor neste esquema iterativo a obscura presciéncia do princípio de que o mito se define pelo "conjunto de suas variantes" (70). O livro Dos Inventores progressivamente se apaga $\mathrm{em}$ face destas redundâncias orais de uma cosmogonia indigena em que, vez por outra, um esboço de comparạ̧a se insinua. As transformaçôes de Maire-Monan lembram a Thevet os encantamentos de Circe(71). e os herdeiros de Maire-Ata, que devem passar por uma série de provas que demonstram a origem de seu sangue, sâo relacionados com os cavaleiros que " foram destinados a conquista do Santo Graal na Grá-Bretanha" (72). A comparaçăo, de moldura estruturante, fica reduzida a um motivo ornamental que preenche o breve espaço dos incisos, marcando as pausas subjetivas na longa litania dos avatares dos herois civilizadores.

Por sua desordenada precisão e fidelidade ao objeto, a obra brasileira de Thevet testemunha uma espantosa e paradoxal modernidade. Compreende-se então que a hierarquia excessivamente rígida a qual tendia o comparativismo unívoco de Polidoro Vergílio tenha sido inadequada a esta proliferaçăo do material mítico. Recipiente impróprio, incapaz de regular a complexidade dos dados etnográficos, a mitografia vergiliana tornava-se inaceitável para um cosmógrafo entregue a si mesmo, uma vez consumado o divórcio com o verniz de humanidades clássicas dos escribas. os Mathurin Héret e demais François de Belleforest.

Mas há mais: se se referir uma última vez as Singularidades, obra de transição entre a compilaça escolar da Cosmografia do Levante e as amplas mitologias do livro XXI da Cosmografia Unitersal, descobre-se que o tratado Dos Inventores representa em Thevet um papel mais ambíguo do que se diz. Ocorre que a meio-caminho entre recipiente e conteúdo, Polidoro Vergilio mantém uma relaçăo com o "pensamento selvagem" do tipo " rizomático", se se quiser retomar aqui a categoria proposta por Gilles Deleuze e Félix Guattari(73). Com exceçấo dos capítulos sobre a religiảo, $\mathrm{cm}$ que a relaçăo hierárquica de inclusão e exclusấo é claramente indicada, o privilegio destinado a cultura ocidental e cristả nem sempre aparece com grande nitidez, tanto é poderosa a atração que exerce a novidade sobre o peregrino dos dois mundos. Tece-se entăo uma ligação lateral, por imbricạ̧ăo recíproca, entre a tradiçẫo humanista e a "trađitiva" indigena, transmitida de boca em boca.

Através de uma perversão que, sem dúvida, năo previra ou medira Héret, a mitologia indigena contamina com os seus efeitos o discurso do "singularizador" Observou-se acima que, no capítulo consagrado à agricultura, a "lavoura de Abel" . fruto de uma leitura distraida da Bfblia, viu-se confirmada pela cultura da mandioca e das favas entre os tupinambás. O mito de origem dos índios vem reforçar a autoridade das Escrituras em detrimento das fiç̧ôes dos poetas gregos e latinos(74). $O$ mito da origem do fogo, que se liga a "opiniảo dos selvagens a respeito de um dilúvió (75), acarreta agora uma outra espécie de confirmaçáo. Diodoro, cuja opiniăo é transmitida a Thevet por Polidoro Vergílio, atribuia a Vulcano a invençâo do fogo. Era afirmar que a humanidade nem sempre fora detentora deste precioso instrumento de cultura. Ora, os índios năo pensavam de outra forma.

$$
\text { " os quais, antes da inveņ̧ăo do fogo, comiam carnes secas à fumaça" (76). }
$$


la máxima da Fisica transformada em provérbiơ" seggundo a qual năo há " fogo sem fumaça" ou. reciprocamente. fumaça sem fogo(7/). Mas o pensamento selvagem, ao que parece, tâo familiar ao cosmógrafo quanto aos índios, opóc um desmentido cabal à razĩo pensante de Léry e ao auxilio que ele pretende obter dos provérbios usuais Com cfeito, a oposição de fogo e fumaça e menos absurda do que parece a primeira vista. A antropologia cultural de C.laude Lévi-Strauss habituou-nos a distin: guir as "categorias empiricas" do cru e do cozido, do defumado e do assado, que servem de instrumentos conceptuais ao pensamento selvagem. Neste caso, a carne seca a fumaça - ou então ao sol, nas variantes Gê sobre a origem do fogo(78) aparece numa relação de contradição com a carne cozida ao fogo de lenha: aí está toda a clistância que separa a natureza da cultura e que a intervençio do grande Caraiba Maire-Monan permitiu superar. A julgar por Thevet, muito sensivel às infle. xổes do pensamento tupi, este conhecimento teria sido comunicado aos índios durante o sono, "algum tempo depois de um dilúvio, que eles afirmam ter ocorrido outrora" (79).

De um lado e outro desta noite da revelaçăo, duas etapas da historia separam-se definitivamente, da mesma forma como a humanidade apta a arte culinária vira as costas ao animal condenado a devorar alimentos crus. A transformaçào do alimento pelo fogo afasta de uma vez por todas a naçâo índia de suas origens cegas. $\Lambda$ simples fumaça, ao contrário, traçava em relação a animalidade apenas uma fronteira inde. cisa e precária, que o domínio do fogo de cozinha reconstitui $\mathrm{cm}$ toda a sua nitidez. Situado além dessa ruptura fundadora, o canibalismo tupinambá, iluminado pelo claráo das fogueiras, jamais parecerá táo escandaloso ao observador curopeu quan. to poderia ser a omofagia dos míticos Antropofagos da Antigúiclade ou a dos nato menos lendários "Canibais" do Nordeste brasileiro, nos quais Thevet reconhece, sem hesitar, "leōes arrebatadores" (80). O crivo instaurado pelo mito é entảo con. duzido para a descriçăo, e a relativa indulgencia do singularizador pelos banquetes sanguinários, interpretados espontaneamente como ritos de vingança, explica-se muito bem pela transferência dos instrumentos mentais dos índios ao universo de referência do curopeu. É verdade que uma clistância diferencial menor do que a atual entre as duas culturas contiguas facilitou a osmose ou a propagação subter. rânea e "rizomática" (81).

Em última análise, nâo se pođe dizer se Thevet, numa passagem como esta, adaptou a realidade india a Polidoro Vergílio ou Polidoro Vergílio a imperiosa logica mítica dos ameríndios. Quando, depois das Singularidades, obra contemporânea da empreitada colonial, que deixava vislumbrar perspectivas missionárias, ficar menos nítido o caráter didático, $c$ até apologético, présente na relação thevetiana, o pen. samento selvagem dos tupinambás não estará mais cerceado pelos fins de capitulo sentenciosos, que reduzem infalivelmente a alteridade cultural a identidade univer. sal đa verdade cristã. Entẫo a bricolagem mítica đos brasileiros pođerá reunir-se a do cosmógrafo, também ele "colado às imagens" (82), para constituir a partir das unidades concretas que sấo as "singularidades" uma ciência a meia-distância entre o percebido e o conceito.

\section{Notas}

1 Thevet, Hi, U, vilt cap. 140 a 145 respectiramente.

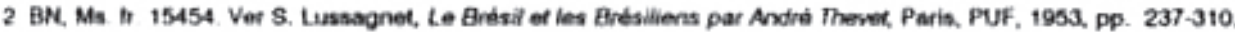

3 BN. Ms. H. 15452, mapas ne 92 a 95 e 90 a to1. Na ordern. "lales de Maquehay" (Macad), t. 225 vo., ma.; " tale dee

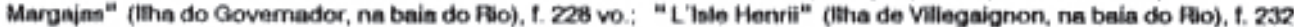

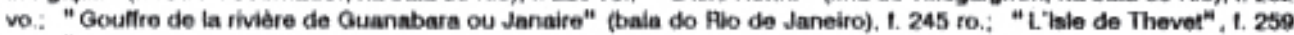

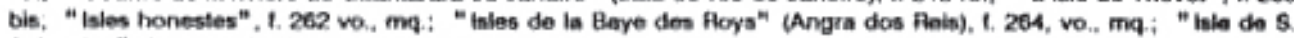
Sebantien" (thitha de Sảo Sebastiko), 1. 265, vo, mq.

4 Thevet Cosmografia Unversar (1575). t t. 116 r., e it. 941 ro.

5 Thevet, Cosmografia Unwersal, 1, 11, cap. 16, 1,64 wo. Pasnagam racopeada por Louls Qupon do la Nauche, Las Owerses Leçons (Lyon, Claude Morillon, 1604; reed em 1610), Ivro W, cap. 28, p. 748.

6 Thevet, Cosmografia Universat, 1, V, cap. 1, t. 121 ro.

7 Thavet, SFA cap. 66, 1.131 10

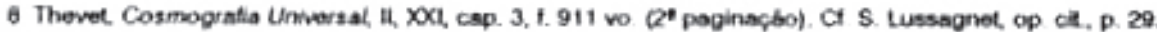

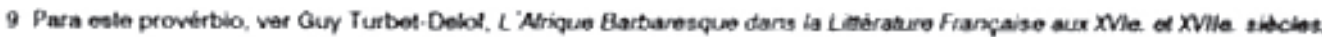


Genebra. Droz. 1973. p. 42 Sobre o antagonismo Tutco o Mouro, ver tambem a minha comunicaçâ "Guillaumo Postel ef I'Otsession Turque", in Actes do colóquio Guillaume Postel (158t-1981), Paris, Guy Trédaniel, 19a5. p. 265 sq. e especialmente pp. 270-1 e 281-2: "Bom Turco e Mouto Cruet"

10 Thevet, Cosmografia Univorsal, I, VI, 1.1. 151 vo.

11 Thevet, Cosmografia Universat, 1, VI, 5, 1.163 ro.-vo

12 Melusina: SFA cap 81, 1. 160 to: "o Proteta ingles Merlim": Cosmografia Unversal, 11, XX1, cap 6, 1.919 ro, (S. Lussag net, p. 67): "a conquista do Santo Graal na Grả-Bretanha" : Cosmografía Universal, II, XOX, 6, I. 920 ro. (S. Lusangnet, p. 71$)$

$13 \mathrm{Cl}$. o titulo do capitulo IV do Inro XXI: "Do Cabo Frio e a Leviana Crença dos Selvagans da Mencionada Pogiào"

14 Thevet Cosmografia Universal, II, XIX, 10, I. B51 ro: "Porque uns adoravam o Fogo, outros as Florestas, outros as Serpentes, outros o Sol e um Martelo de tamanho e grossura monstruosa. E como perguntaram lhes por que prestavam tal homenagem ao Martelo, eles responderam que outrota o Sol esteve muito tempo sem thes mostrat sua claridade: mas finalmente como ele surgiu, o Rei do pais tomou-o e aprisionou o numa torre enorme: mas os Signos do Zodiaco ao virem em socorto do prisioneiro, quebraram a torte com o dito Martelo, e libertaram o Sol: E para esta boa nçho. eles hontararn o Martelo, que tanto fizeta pelos homens ao thes devolver a claridade do Sol"

15 Thevet. Cosmografia Universat, II, XVI, 11, 1, 674 ro: "AJ6m disso, no tempo ern que o mat esth congelado. algumns vezes o gelo se quebra. fazendo um barulho como so loses uma voz humana: isto é causa de que o pobee povo simples e grosseiro dnquela regibo cteia o ostime que sảo as nimns dos talecidos, que ali esthio sondo atormontadas a all passarn o tempo de sua penitência, do tal modo a idéia do Purgatório entá gravada no espirito da naçáo.

- Segundo Olaus Magnus, Historia de gentibus septertionalibus, earumque diversis statibus, conditionibus, moribus, rifibus, superstitionibus, disciplinis, oxercitis, regimine, vict, bellies, structuris (..) ef rebus mirabilibus, (Pome), 1555. liber secundus, caput III: "De apparentibus umbris submersorum: "Ibiquo ( = in Islandia) locus asse creditur poenae, expiationisquo sondidarum animarum. Hic nempe spiritus, seu umbrae, comperiuntur se exhibertes manilestos humanis ministeriis submersorum, sive alio violonto casu enectorum. Cl. o epitome publicado em 1561 em Antubrpia por Chrietophe Plantin com o titulo de Histoire des Pays Septertrionaux, II, 3, t. 20 ro, vo: "Ha nesta Ilina colsas admirituois e como que milagrosas. Entre outras, ha um rochedo que queima o arde continuamente como faz o monto Etna (ou Mongibel) e os habitantes da regiấo acreditam que 6 um precipicio do inferno no qual as almas dos falocidos lazem penitência. E dizem que ai se costuma ver almas e espiritos mostrarem-se reveladamente (..).

- A passagem em questito da Cosmografia Universal de Thevet podo ser relacionada com o mito rabelaisiano das Palavras congeladas (Quarto Livo, cap, 55-6), ao qual replicat a mais tarde o cosmógralo no GI, I, I. 147 ro - 147 vo. (ver R. Schlesinger e A. P. Stabler, Andrd Thevet's North America, Montreal, 1986, pp. 235-6)

16 Thevet. Cosmografia Unmersal, 11, XX1, 1, 1. 905 vo.-906 ro. (20 paginacho)

17 Thevet Cosmografia Universal, II, XVI, 11, 1. 674 fo

18 Ver Ellriede Pegina Knauer. Die Carta Marina des Olaus Magrus von 1539, Góntingen, Gratia-Verlag. 1981, p. 41 sqq. " Der mehrfache Sinn der Carta Marina.

19 Thevet, Cosmografia Unversal, I, I. 190 vo. Sobre as circunstancias dente milagre e oco conaiderável dado a ele pela propeganda contra relormada, ver François Secret, L'Esoterisme de Guy Le fàve de La Boderie, Genebra, Droz. 1969. p. $17-8$.

20 Thevet, Cosmografia Unmersal, 1, D, 5, 1. 294 vo

21 Idem, ibidem.

22 Thevet. Cosmografia Universal, 1, XII, 10, 1. 441 ro.: "Isto também observei entre os Solvagens da Antártica: os qunis vendo que comiarnos toucinho volho e rançoso, que lazia as vezes do galos capóes a perdizes, repreendiam-nos dizendo como er a posshol podermos viver thio longarmente e que estivb́ssernos com vida, visto que aquela sujeira era inteiramento dariosa ao corpo dos homens.

23 Thevet, Cosmografia Univorsat, ibidern, na sequèencia da passagem peecedente.

24 Thevet, Cosmografia Universal, 1, 11, 8, 1. 49 ro. O trecho 6 utilizado para refutar as "asneiras de Pomponius Mela, no falar do lago Themyns no Egihto, onde se veria "uma itha flutuante sobre a água, "de um tamanho espantoso, cobertn de "paisagens, terras incultas, bosques, florestas e, em alguns lugares, belas cidades. A relerbncia aos" meus Selva. gens da França Anthrtica é enthio destinada a desvalorizar a peseudociência dos Antigos.

- A mençào aos selvagens do Brasil, em sua tunçảo de desqualificaçào, encontra-so no Grande Insular (11, $t$. 118 vo. 119 to.). para condenar as afirmaç6es de $\mathrm{S}$. Münster no tocante as tontes da juventude, Cereu a Nelbia, situadas antigamente na ilha de Eubtia: "Oue se ele talasse a verdade, haveria vários mithares de pessoas que, tristes de estarem com a barba branca, nbo poupariarn dinheiro para viajar ate as fontes milagrosas, e mandariam vir Agun para

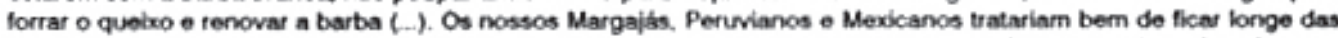
fortes, urna vez que, corno ja disso, eles afrancam todo os polos do rosto (. ) Mas isto be partagruelizar demais

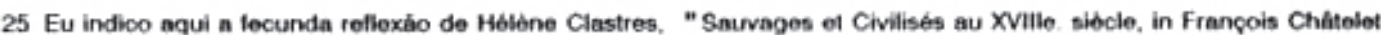
(ed.). Les Idbologies, Paris, Hachette, 1978, e Marabout Uniwersite, 1981, t. III, pp. 191-210.

26 Sobre o trabatho de De Gerando e seus pressupostos ideológicos, ver, além da relerb́ncia dada à nota precedento, o estudo de Brita Pupp-Eisenreich, "Christoph Meiners of Joseph-Marie de Gérando: un chapitre de comparatisme antropologique. in D. Drobche e Pol.P. Gossiaux (ed.). L'Homme des Lumiàres ef la docouverte de l'autro, Bruxelas, Éditions de I'Universite de Bruxolles, 1925, pp. 21:47

27 Paul Jove (Paolo Giovio). Histoires (Lyon, G. Rouille, 1552, Irvtos XVII e XVIII, p 277 sqq.), lorneceu especialmente a Thevet, Cosmografia Universal, I, f. 37 -38, o retnto da tomada do Cairo por Selim erm janeiro de 1517. Sobre n colethnea de Sansovino, ver Stephane Yérasimos, "De la Collection de Voyages a I'Hlistoire Universelle: la Historia Universale de Turchi de Francesco Sansovino, in Turcica, $t . X X, 1988$, pp. $19-41$ 
28 Sobre doès destes "colóquios, ver David Dalby o P. E. H Hair. "Le Langaige de Gurnee: a sixteanth century vocabulary from the Pepper Coast, in Arican Language Studies, V. 1964, pp 174-91 e "Le Langaigo du Brbsil A Tupi Vocabulary of the 1540s, in Transactions of tho Philological Sociecy 1966, Oxtord, 1967, pp 42 66

29 Segundo o diciondurio de Littré, s.v. " margajat, que, para o sentido figurado, dá dois exemplos tirndos do Boursault e Voltaire Thevet, que emprega pela peimpira vez a palovra em francés ( Cosmografía Universat, It, XXX., passim). náo é mencionado

30 Thevet, Cosmografia Universat, 1, 1. 137 ro

31 Thevet, Cosmografia Universal, II. XXI, 14. I, 941 to vo C1. S. Lussagnet (ed.). Le Brésil ef les Brósilians. 1953. P. 178.

32 Thevet, Cosmografia Universat, II, XXI, 5, I. 916 vo. (S. Lussagnet, p. 55) Cl. Thevel, H2V, I. 47 vo., em que esta passa gom 6 rotomada.

33 Thevet, HI. II, liwro VI, cap 103, I. 530 ro. 532 vo: "Pobert Gaguin - Sobee a obra de Pobort Oaguin, consultar-se-á peincipalmente Franco Simone, II Rinascimento Francesi, Studi o Ricerche Turim. Societa editrice Internazionale, "Bi. blioleca di Studi Francesi, $n^{0}$ 1, 1965, 1, cap. 2, 3 o 4

34 Irata se do jurisconsulto Jasto de Mnino ou Mayno (14:35-15:9). Ver Michel Reulos, Comment Transcrire er Interpreter les Adthrences Jundiques, Gendvo. Droz 1965

35 Thevet, HA, II, f. 532 vo, in fine.

36 Ver Suzanne Lussagnet, op cit, 1953, p 40, notn 1 - Poder se ia evidentemente. pensar am outro tipo de apeoxima çbo onomística o maire relacionando-so. pola etimologia latina ao maior no sentido de ancestral, de primogdrito ou de perincipal fver os diciontrios de Godefroy. Huguet e o fEW de Walter won Wartburg. s. ₹. maion Mas nho bé segure que Thevet empreque alhures esta palevra, com o actibcimo deste valor de substantivo, onquarnto que o tupinambd maira. afrancesado em mair(e), tem um emprego Inmiliat apos a Cosmografia Universal. O que reforça nossa hipobtese

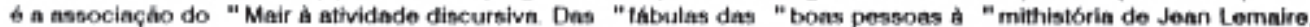
a funçêto dos maires do Btasil a da Françe se encerra nob o termo generico de "discurso - e, em especial, de discurso das origans

37 Thevet, Cosmogratia Universal, II, XXI, cap, 4 n 6 . "Do Cabo Frio e da leviana crença don Selvagons da dita regieao: " Instituiçáo do grande Caraiba e das translormaçós produzidas por seus proletas; "Sentido das translormaçóes e crenças deste povo (cap. 3 a 5 da ediçáo de $S$ Lussngnel)

38 Heltone Clantres. La Terre Sans Mal. Lo Prophotisme Tupi-guaran, paris, Editions du Seuil, 1975, p. 51

39 Thevet. Cosmografia Universal, II, XXI, 6, 1,918 ro: ct HZV, I 48 vo

40 Ver as notas 54 e seguintes do capitulo ll de L 'Nelier du Cosmographe

41 Ver notns 106 a 108 de Le Huguenot ef le Sarvage. Paris, 1990, cap III. para releréncia dis circunstAncins historicas desta tradupho

42. The New Found Worlde, or Artarctihe (. ) Travailed and Wrimen in the french Tong, by that Excelled Lealmed Man, Masiov Andrewe thovet, Londres, by Henrie Bynneman, for Thomas Hacket, 1568. I. "2ro.. (carta) "To the right honorable Sir Henvie Sidney, Nuight of the most Noble order of the Garter, Lorde Presidert of Waies, and Marches of the same, Lord Deputie Gevorall of the Queenes Ma-jiesties Aealme of lrelard, Your humble Orator Thomns Hacket wisheth the tavoure of God, long and happy life, encrease of honor, continuall toanth and felicitie. Eis aqui o inicio dentn epiatola: "None are morn to be commended (right Honorable) than those who wer the first imenters and finders out of Avtos and Sciences. whorwith mankind is beautified and adomod, without the wich giltes he were but naked, barbarous and british. you arnd a servile creature. It was not lor nothing that the elders in Nimes past did so muche celebrato the instituters of those things. as Herodotus writoth, that the Egiptians belore all other men firstound out the yere by the course of the Planers, and devided a irto xy morthes. Diodorus assigned it to the Thebarnes, the which standeth well with the opinion of Hercodotus, bicause the Thobanes be a nation of Egipe. As Numa added to the yere Lanuary and February, Romulus ordred Marcho, Aprill, and Mary, Augustus an ocher part, and so luflius Coesat made up the perfect yeve, as Polidorus Vergilius witnesseth in his boke Do imvontoribus rerum.

Sobre o peojeto de Polidoro Vergilio, consultar-30-6 a obra de Denys Hay. Polydore Vergil. Reraaissance Historian and Man of Leters, Oxdord. The Clarendon Press, 1952. cap. III: "De Inveruoribus Ferum, assim corno um capitulo de Jean Sernoc, La Survivance des dieux antiques, 20 od. Patis. Flammarion, 1980, cap. L. p. 25 Mns, no contrario do que pensa Seznec, nho sbo os excessos evemeristas que levaram Polidoro Vergilio a ter seu Dos Imertores mencionado no index, posém, muito mais, o seu erasmianismo. Corn oleito, a odiçảo aumentada em 1521 da compilaçho roservava o melhor quinhto para a Igreja Primitiva e criticava as "invornçoes, em matéria de instituiçáo ocienihntica, postoriotes ao tempo dos Apóstolos. Este é o contećdo subvorsivo, que in na mesma difeçào da Epitome Topographica de Vadianus, visado

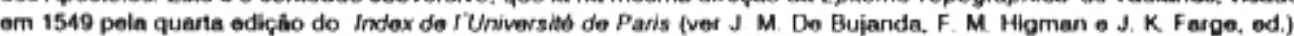
Shorbrooke o Genebra. 1985, p. 249, no. 243.

Denys Hay, op. cil.. p. 65, sublinhou justamente a vioulencia com a qual, na dedicatória dos cinco ultimos livros actos. centados em 1521. Polidoro Vergilio denuncia "the jungle of Judaic observances spreading over the fioid of the Lord Eo que o taz condenat os padres que encornjarn o povo a venerar as imagens da Sagrnda Farnilia a indignar-se com o combrcio das relliquilas.

Nern Heret, nem Thevet, naio mais que Bellelorest, alits (ver mais alem a nota 45). parecem chocados com semelhantes auditcins.

43 tbidem, 1. "3 vo: "Thus (right honorable) we see, the valiant and curagious personages of the workd have brought to passe mary excellert enterprises, so that their name shall nower dyo, atcherved as well by sea as by larnde, as this worthy travedler Anderwe Thervet, in this his Navigations of the Now lound World, which 1 have dedicalod unto your horor. .

44 Vet Pierte Françoes Fournier, "Un collaborateur de Thevet pour la rédaction des Singularites, CIHS. Bullotin de la Section de Gitographia, t. XXXV, 1920, p. 39-42, a notas 50 a 51 de meu estudo André Thever, cosmographe des derniers Valois, Genebra, Droz, 1991, cap. IV 
45 SFA cap. 30, I. 57 wo. CT. Polidoro Vergilio, livro II, cap. 9, "Daquele que em primeiro lugat enoontrou a arte de memória: demonstrou-a e dequales que nela floresceram, 1.63 vo: "Ciro, rei don pernas, possuia tanta membria graças a esta arte. que dizia lodos oe nomes dos homens do seu exército. Cinbas, legado do rel Pirro, no dia seguinte do sua chegada em Roma, nomeou de memória todos os homens orn qualquer ordem, Mitridates conheceu vinte a uma línguas (..). Nos diremos ainda que César lia e escrevia, compunha e escutava, no mosmo tempo, segundo Espartiano. Citamos segundo a traduçbo francesa de 1544: Pollidore Vergile hystoriographo nouvellemert traduict de Latin on Francois, declairart les immonteurs des choses qui ort estbe, Paris, Jehan Longis o Vincent Sertenes (BN: Q. 29945). Tnmbern consultamos a tradupho francess de Belletorest, Les Mernoires ef histoire do I'onigine, imention a autheur dos choses. Faicte en Latin, of dwisee en huic tivres, par Polydore Vergile natif d Urbin: ex tractuicte par Frangois de Belie-forest Comingeois, Paris, Pobert Le Mangnier, 1576.

46 Thevet, SFA cap. 31, I. 59 ro.

47 Polidoro Vergillo, Les Imenteurs des Choses, 1544, Iivro III, cap. 17. Cl. Belleforest, trad. citada, p. 350: " Plutarque en son Theses. - Neste ponto 6 preciso corrigir minha ediçáo das SFA 1983, p. 61, nota 3, ern que ou indicava Plutarco (Vie de Thdsde, cap. V. "Bibl de la Plbiade, pp. 4-5) como fonte da passagem. Na verdade, Pollidoro Vergilio serviu de intermedidrio, o talvez al esteja a origem do contra-senso de Thevet, loc. cit: "E de fato consideramos que Alexandre. rei da Mncedonia, ordenou a sous homens que agarrassem os macedónios pelos cabolos o barba, que tinham longos. porque nito havia entho barbeiros para corta-los ou raspá los.

48 Thevet, SFA cap, 36, f. 68 vo: "Desta (= a magia) diz-se lerem sido imventores Zamolxis a Zoroastro, năo aquelo tho conhecido, mas o filho de Oromasio. Ct. Polidoro Vergilio, op. cit, 1, 22; trad. de F, de Bellelorest, 1576, p. 119.

49 Thevet, SFA cap. 35, t. 65 ro,: "Nós concordariamos neste ponto com Filon, o primeiro a interpretar oa sonhos, a segundo Trogus Pompeius, que depois loi também excelente nesta mesma ciéncia. Segundo a opinibo de Plinio. loi Anficteon o primeiro interprete. Ct. Plinio, Histoire Naturelle, VII, 56. O capitulo intitulado "Des Premiers Irventeurs de Plusieurs Choses (trad. de Antoine Du Pinet, 1581, pp, 286-90) b largamente utilizado por Polidoro Verglilo. Cl. a traduçáo de F, de Bellelorest L, 24, p. 127

50 Thevet. SFA cap. 38. I. 71 ro.-vo.: " Ao serem atacados, oles lançarn flechadas uns nos outros contusamente, dibo golpes de maças o espadas de madeira, a ponto de nho haver passatempo melhor do que vor sernethante relrega. Agarram-ne o mordern-6e corn os dentes orn todos os lugares que possam enoontrat, através dos seus labbios porturados.

Esta guerra sehvegem, cuja pintura parece feita ao vivo, inspira se de fato num modelo traçado por Polidoro Vergilio (II, 10, od. do 1544, t. 64, ro.-vo.): "Os antigos, antes do uso das armas, usavam hutar com punhos, calcanhares e mordendo com os dentes: esta era a primeirn manoira des batalhas. Em seguida, combatou- so ntirando pedras a com golpes de cajado, segundo o testemunho de Heródoto em seu livro quarto (...). Diodoro afirma em seu livro primeiro que as maças a a pele do lobo erarn apropriadas para Hercules combater, uma vez que, nem antes, nem ern sou ternpo. haviarn armas. As injürias eram vingadas com grandes maças de madeira e a gente do armas estava coberta e protegida apenns com peles de animais.

- Assim, se for seguide a liçho de Polidoro Vergillo, observa-se que os tupinambás reuninm, om seu modo de com. bater. varios estágios distintos da imvençlo da arte da guerra

O mesmo capitulo 38 das SFA de devedor ainda de Polidoro Vergilio no que concerne à origem dos tratados (t. 70 vo.): "Penso que se ali estivesse Teseu, o primeiro autor das tréguas entre os gregos, ele encontraria mais obetheuloa do que em sou tempo. Segundo Plutarco, Vie de Thessea, cap. XXXVII (Bibl. de la Pléiade, p. 29), via Polidoro Vergilio, livro II.

51 Thevet, SFA cap. 42, L. 80, ro, a respeito dos "Cris, povo da Trícia. segundo Polidoro Vergilio, L, 4, ed. de 1544, t, 11 " Da orlgem do casamento, como os povos dilerem neste sacramento e daqueles que, em público (A maneira doa animeis). juntaram-se carnalmente.

52 Thevet. SFA cap. 47. I. 91 vo,-92 ro., sobre a economia de troca anterior ao uso da moeda do ouro, Segundo Polidoro Vergilio, III, 16, ou Plinio, VII, 56, ed. Du Pinet, p. 288

53 Thevet, SFA cap. 53, I. 102 vo. Segundo Polidoro Vergilio, II, 14, ed. de 1544, I. 124: " Ovidio, entratanto, na oltava de suas metamortoses diz que Perdris, sobrinho de Dbdalo, por causa de sua irmá descobriu a serra: pela semethnnça da espinhe, em torma de pente, que hi no dorso de um peixe. Ct. Ovidio, Metamorkoses, Vill, vernos 256-8. - A mesma pégina de Thevet toma ainda emprestndo de Polidoro Vergilio as tradiḉ̄es sobre a origem dns" lerrarnentas, tals como "cunha, "sorra." "lima e pregos (Polidoro Vergitio, ibidern)

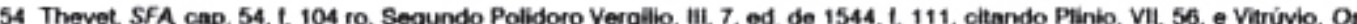
Daz Livros da Aquitetura, II, 1, onde b evocada "a vida dos primeiros hornens antes da invençấo do logo e das habitnçôes fixas. Polidoro Vergilio: "Todos comecaram a pensar em algum remb́dio contrn o trio e a geada, e loi asaim que se construiram pequenas ediflcaçós de barro e peredes feitas de terra comum, que se mantinham de pé por maio de varas a galhos entrelaçados com gravetos e vimes.

S5 Thevet SFA cap, SA, I. 112 vo. 113 vo, sobre a vida dos primeiros homens e a origem da agricutura. Polidoro Vergllo, III, 2, ed. de 1544, I. 99, jh produrira uma pequena sintese sobre a questía. A ele Thevet deve particularmente, $\mathrm{t}$. 113 vo., a relertencia a Virgilio, Gebrgicas. 1. verso 125: "Antes do Jüpiter nenhurn lavrador trabalhava a lerra...

56 Para Tesou, ver as notas precedentes 47 o 50 , in fine; para César, ver a nota 45 . Quanto a Liourgo o Soblon, legisladores de Esparta e Alents, as Vidas gêrmens redigidas por Plutarco recomendaram aos hornens do Plenascimento as sunat sabedorian antitb́ticas. Thevet mostrou-so tributário na $\mathrm{CL}$ cap, XXVII a XXVIII. Ele evoca ainda o exemplo de Solon nas SFA cap. 51. 1. 96 vo.. a respelto das restriçbes impostas ao combrcio do mel, segundo, sem dúvida. a afirmaçểo de Polidoro Vergllio.

57 Thevet, HI, II, VIII, cap. 149, 150, 147 e 145, na ordem em que loram enumerados por nos.

SA Todos eles "inventores mencionedos no capltulo 56 do Imo Vil da Históvia Natural.

59 Para esta filinçio, ver Denys Hay. Polidor Vergil, Reinassance Historian and Man of Letlors, Oxdord, Clarendon Preas, 1952, conp. III, p. 58 
61 Thevet, SFA cap. 58, 1, 113 vo. De acordo com Polidoro Vergilio, II, 2, od. de 1544, 1. 99: "No comeco, segundo Plinio no preâmbuio so dbcimo-sexto limro do suns histórias naturais, a natureza máe de todos o de tudo nbo ensinava sos homens viver tho berandarnente quanto hoje. Porque contentavam-se com os frutos da terra produridos e engendrados sem que ela fosse lavrada, corrompida ou vilada polas lerramentas, assim como diz Ovidio Naso na primeira de suas Metnmoriosos (...). Virgllio diz a esse respelto, na primeirn de suas Gebrgicas (...) O labor foi ecrescentedo o unido acos centeios e outros trigos quendo se soube que as florestas queriam ser estereis: e mosmo a de Dodona fit comegava a recusar sou frulo (..).

62 Corno mostra Du Bartas no Edon (Seconde Semaine, Premier Jour), verso 271 sq9. Ver sobre este ponto a minha comu. nicaçấo: "L'Art imilte la Naturo / La Nature imite I'Art: Dieu, Du Bartas et r'Éden, in Actos du Colloque Guillaume de Saluste du Bartas (Pau, 1966), Lyon, La Manufacture, 1988, pp. 167-84.

63 O lapeo de Thevet (SFA L. 113 vo.), que alastou Caim em proveito de Abel, o pastor, provocart os sarcasmos de Jean de Léry, HIV, $3^{\circ}$ ed. Conebra, 1585, Preticio, L q9q3. "Ele publicou sua ignoríncia ao dizer que as Santas Escrituras tazem mençito da lavoura de Abel, uma vex que, se ele puser os bculos, vera que este era pastor de ovelhas, o seu irmào Caim lavrador do terra.

64 Thevet, SFA cap. $36,1.68$ ro.

65 Thevet, SFA cap. 35, 1,65 ro.-vo. A concluabo do capitulo 6 tho significativa quanto inexata: "...6 sho roalmente idólatras, nem mais nem menos que os antigos Gentios.

66 Ver sobre este ponto Suzanne Lussngnet, op. clt., 1953, p. 39, nota 2, o p. 45, nota 1 . A oplnifio do diliúvio 6 evoceda nas SFA cap. 53, 1. 101 vo.- 102 ro. E sabida a importíncia que os missionarios darío a este mito, onde descobrem a prefiguraçấo do cristianismo a prova da unidade da Rovelaçálo.

67 Thevet, SFA cap. 58. Para a invençato de cultura dn betata-doce e do milho peilo mesmo Maire, ver Cosmografla Univer. sal, II, XXI, cap. 6, t. 918 ro. (S. Lussagnet, pp. 61-2). CI. M2V, t. 48 ro.: Maire-Monan, que surglu como avatar de uma criança e foi surrado pelos indios, "tazia chover sobro olos raizes, chamadas Yebic, que eram como os nossos rabanetes, e painco, que chamarn Avary.

68 No capitulo XVI de sua HIV.

69 Suzanne Lussognet, pp. 39, 43-5, - 66-72. C. Pierre Clastres (Lo Grand Parler. Mychos of Chants Sacrbs des Indiens Guarani, Paris, Seuil, 1974, Pp. 95-9), que reprodur, sob a rubrica de "Aventures des Jumenux, um lerpo excerto da Cosmografia Unvevsal, II, 1. 919-920, transcrilto anteriormente por S. Lussagnet pp. 66-72.

70 Claude Levi-Strnuss, Anthropologie Struchurale, Paris, Plon, 1958, cap. 11: "La Structure des Mythes, p. 252.

71 Thevet, Cosmografia Universal, 11, I. 918 vo. (S. Lussegnet, p. 65).

72 Thevet, Cosmografia Universal, II, I. 920 ro. (S. Lussagnet, p. 71).

73 Gilles Deleuze o Follx Qunttart, Fhizome (Introductiont). Paris, Minuit, 1976. O sistema" "rizombtico deline-se por oposçäo ao sisterna arborescente (hierarquizado), Q. por outro lado, ole se caracteriza pela abertura para o oxterior (p. 66).

74 Thevet, SFA cap. 58, t. 113 vo.

75 Thevet SFA cap. 53, 1.101 vo. a margem.

76 Thevet, SFA ibidem. Na passegem equivalente da Cosmografia Univorsal (OXI1, 12, 1937 , vo.; S. Lussagnok, p. 161). Thevet nilo reprodurtu a expressbo abroviada.

77 Jean de Lery, HIV, $2^{\bullet}$ ed., 1580, cap. 18, p. 288 : "Entrotanto, nho quero dizer com isso, ainda menos crer ou tazer orer, o que algubm colocou em seus escritos: a saber, que os selvagens da América (de que pasao a falar). antes da invençếo de lazer logo, secassem suas carnes ha lumaça: porque da mesma lorma que conaidero osta mbíma extraida da Fisica e tranaformada em prowerbio multo verdedeira: a saber, que náo há fogo sem lumaça, também pelo contrário. deduzo ou nilo ser bom naturalistn equele que faz crer que há fumaça sem logo. Eniendo como lumnca, da mesme forma que aquele do que falo quer dar a entender, aquilo que posaa cozinhar as carnes: ussim, se ele, como salvacto, dissesse estar talando de vapores o exalepbes, ainda quo the concedbssernos que as hat quentes, entendido que sejem tais que possarn secar, - que, caso contrário, fosse carne ou peixe, olas os lornariam antes pegajoeos e úrnidoe: a resposta serth que bsto b zomber de lodos. Considerando, pois, que este autor, tanto em sua Cosmogralia quanto alhures, queben-so muito e multas vezes dequeles que, ao nbo falar a seu gosto das matbrias que ele trata diz nho terem lido bem os seus escritos: ropo nos leillores que notem bem a passagem extracordinaria que acebo de conter a respeito de sua nova furnaça quento o estapelúrdia, que mando do volta ao seu cbrebro de vento.

- Paul Gallarol om sua odicblo des Singularidades (Paris, Maisonneuve, 1878, p. 267, nota 1), nibo mostrara main compreensib por uma semelthente" ingenuidede.

78 Claudo Lovi-Strausa, Lo Cru o Lo Dut (Mllokbicas, D. Paria, Plon, 1964, mihos M. 7 a M. 12.

79 Thevet, SFA t. 101 vo.

80 Thevet, SFA cap. 61, t. 119 vo.

81 Para a andilise do "penaamento militico em açấo nas descripobes do canilballamo tupinambd no Renascimento, vor mou

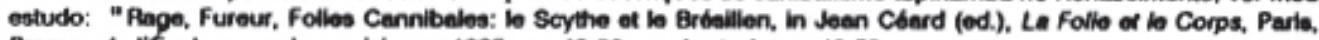
Presses de I'Ecole normale supdrieure, 1905, pp. 49-80, e sobretudo pp. 49-5a.

82 Claude Levi-Strausa, La Pansde Seuvago, Paris, Plon, 1962, cap. L. p. 31: "Compreonde-se assim que o pensamento mitico, embora coledo te imegena, poesa jib ser genernilizador, logo, cientifico. 